\title{
GOING CONCERN COMPANY AND ITS RELATION TO SUSTAINABILITY REPORT DISCLOSURE: EVIDENCE FROM SOES IN INDONESIA
}

\author{
Saktiana Rizki Endiramurti ${ }^{1}$, Achmad Budiman Rosadi ${ }^{2}$, Agung Nur Probohudono $^{3}$ \\ ${ }^{1,2,3}$ Faculty of Economy and Business, Sebelas Maret University, Surakarta, Indonesia \\ Email: qiqi.endiramurti@gmail.com
}

\begin{abstract}
This study refers to the issue that is happening in Indonesian State-Owned Enterprises (SOEs), especially in the case of going concern. The purpose is to provide empirical evidence about the relationship between going concern companies and corporate characteristics on the disclosure of sustainability report. The sample used is a non-financial SOEs company in Indonesia, consisting of 54 companies during the period 2014-2016. This study employs regression analysis of panel data with statistical tool Eviews version 9.0. The results support three out of four research hypotheses, in which going concern audit opinion and firm characteristics assessed through firm size and age had significant influence on sustainability report disclosure. This indicates that the larger and longer the company stands, the company will present the sustainability reporting more fully. The more complete presentation of sustainability reporting becomes one of the important factors for the auditor in determining going concern opinion in its report.
\end{abstract}

Keywords : Sustainability Report; Going Concern; Disclosure; Indonesia.

\section{Introduction}

The sustainability report has become one of the major development issues of the company in recent years. The concept arises because of the demands and expectations of the surrounding community regarding the role of the company in society. The debate continues around the negative environmental and social impacts of disproportionate and unwise use of resources by a business organization (Dilling, 2010; Kolk, 2003). Companies often put aside the social and environmental impacts arising from the company's economic activities. Companies usually focus only on maximizing profits. This is evidenced by the increasing number of cases that occurred in Indonesia, such as the tragedy of mud volcano floods in Sidoarjo caused by PT. Lapindo Brantas Inc. Another example is Buyat bay pollution in South Minahasa caused by PT. Newmont Minahasa Raya (Sari and Marsono, 2013). The existence of such cases enables the stakeholders or commonly called stakeholders, especially investors to start looking at companies that have reported additional information in the form of sustainability report in its annual report (Wibowo, 2014). They assume that companies that have listed the sustainability report in their annual report will have added value compared to companies that have not yet included the report. This is in line with the theory of legitimacy, where the disclosure of sustainability report is one concrete form of the theory. Company legitimacy is 
indispensable for the sustainability of their business (Rossi and Tarquinio, 2017). Thus, many companies are increasingly aware to disclose a report that is not only based on the single bottom line, the company's financial condition, but also focuses on social, economic, and environmental information or also called the triple bottom line (Nurrahman and Sudarno , 2013). Reporting or disclosure of the three information is then called the sustainability report.

When viewed from its definition, sustainability report is a practice of measuring, disclosing, and accountability efforts of an entity's performance in achieving sustainable development goals to stakeholders, internally or externally from the entity (www.globalreporting.org). The guidelines for the preparation of the sustainability report have been regulated by the Global Reporting Initiative (GRI) which has been developed since 1990, where the reporting is made separately from financial statements or annual reports. GRI itself is an international organization based in Amsterdam, The Netherlands, where its main activity is focused on achieving transparency and reporting of a company through developing standards and guidelines for sustainability report disclosure. In the guidelines for the preparation of sustainability reports issued by GRI, there are also indicator in assessing the sustainability performance of a company, which consist of: 9 indicators of economic performance, 34 indicators of environmental performance, and 48 social performance indicators (GRI, 2012). Preparation and disclosure sustainability report conducted by the company is one effort made by the company in proving the accountability of the implementation of responsibilities that have been done correctly and measurable.

In the State of Indonesia, the regulation concerning the disclosure of annual reports has been put forward by the Government in the provisions of Law no. The regulation concerning the delivery of sustainability report has been specially regulated by the Financial Services Authority (OJK) as outlined in POJK No.51 / POJK.03 / 2017 on the Application of Sustainable Finance for Financial Services Institutions, Issuers, and Public Companies. Although the disclosure of sustainability report is still voluntary, but now the disclosure of sustainability report began to become a trend among large companies in Indonesia. This is evidenced in 2012 as many as 41 companies go public that has presented sustainability report. This figure makes Indonesia the highest country in Southeast Asia in terms of presenting sustainability reporting by the company (Meryana, 2013). This is driven by the annual award for sustainability report organized by National Center For Sustainability Reporting (NCSR) in collaboration with the Indonesian Institute of Accountants Accounting Management Compartment (IAI-KAM). The award is intended to give appreciation to the company in Indonesia which has presented sustainability report, either published separately or integrated in its annual report.

By presenting sustainability report, the company can deliver its performance in economic, social and environmental aspect. Based on Law no. 32 of 2009 on Environmental Protection and Management, states that:

"Sustainable development is a conscious and planned effort that combines environmental, social and economic aspects into a development strategy to ensure the integrity of the environment and the safety, abilities, welfare, and quality of life of present and future generations".

The existence of the regulation affirms that corporate responsibility in relation to the economic, social and environmental aspects must be carried out in a sustainable manner reported through sustainability report to be important to every company. With the sustainability report is expected to be able to provide information about social activities and the 
environment is done in a sustainable, so that companies can maintain the continuity of their business (going concern) on an ongoing basis. This indicates that the company that has presented the sustainability report, then the survival of their business will be guaranteed. This paradigm is in line with the results of research conducted by (Mualifin and Maswar, 2016) that the financial performance of the company affects the sustainability report, so that the company that presents the sustainability report will have a higher performance, which further ensures the going concern of their business.

Although research on sustainability report disclosures is still scarce in developing countries (Sahay, 2004; Sumiani et al., 2007; Md. Habib-Uz-Zaman et al., 2011), but as the authors have pointed out above that sustainability report has now become a trend in big companies in Indonesia, including State-Owned Enterprises (SOEs). Although SOEs is an entity that is usually large and owned by the state, but between SOEs and other SOEs remain competitive in showing their performance, both financial and nonfinancial. Many SOEs have presented the sustainability report, both reported separately and integrated in the annual report as one of the strategies to demonstrate their performance. With the number of SOEs that have presented the sustainability report, it indicates that many large-scale SOEs in Indonesia have had a guaranteed going concern. But this is in contrast to the recent news, where there is an increase in the number of SOEs in Indonesia who suffered losses, which could result in bankruptcy. This is confirmed in the news released by detikFinance on August 29, 2017 and then that there is a list of 24 State-Owned Enterprises are still experiencing losses, where some SOEs are classified into largescale companies and has been long standing. When viewed from the list submitted in detikFinance, there are several SOEs that have reported sustainability report in its annual report.

The existence of events that are irrelevant to the existing paradigm makes the researcher feel that the matter concerning the company's going concern and the characteristics of the company on the disclosure of sustainability report is important to be traced back, especially to the nonfinancial SOE companies in Indonesia. The researcher will assess the going concern of the company by looking at going concern audit opinion issued by independent audit. The going concern audit opinion is an opinion issued by the auditor to ascertain whether the company can maintain its viability (SPAP Section 341, 2001). When a company is deemed unable to maintain its survival, the auditor will issue a going concern audit opinion. In addition to using going concern audit opinion, researchers will also see the state of the company's financial health using the Altman Z-score calculation model. The existence of these two independent variables makes this study different from previous research on sustainability report (Dissanayake, D., Carol, T., and Maria, XL, 2016; Liu and Anbumozhi, 2009; Sumiani et.al., 2007; Dilling, PF 2010). Furthermore, to assess the firm's characteristics, the researcher will use firm size variables and firm age as used in previous studies (Dissanayake et al., 2016; Sumiani et.al., 2007; Dilling, 2010; Delaney and Huselid 1996).

\section{Literature Review}

\subsection{Theory of Legitimacy}

The theory of legitimacy refers to the relationship between a company and the surrounding community, where the theory is used as a foundation for the company in order to pay attention to what the community's expectations are about with the company's business objectives. This theory is expected to be able to harmonize with the prevailing 
social norms in society with the continuity of the company's business activities (Mualifin and Maswar, 2016).

Based on this theory every company can operate, one of them due to the permission of the surrounding community. Thus, if the company does not carry out its responsibilities to the surrounding community, then the public may revoke the company's operational permit (Sari and Marsono, 2013). Information on the disclosure of corporate relationships with social organizations, communities, and the environment can be presented in sustainability reports. The report became one of the evidence of public accountability that aims to gain the legitimacy of the surrounding community associated with the company's operations. In addition, with the disclosure can be known social and environmental impacts resulting from the company's operations.

The theory of legitimacy is based on the idea that an organization or company will be able to guarantee its existence if the community realizes that the organization or company is operating for a value system that is in harmony with the existing value system within the society itself. Legitimacy occurs when the actions of an organization or company are deemed appropriate or appropriate in some socially constructed system of norms, values, beliefs and definitions (Suchman, 1995, p. 574). Thus, the purpose of this theory is that the company can ensure that all activities and business performance can be accepted by the surrounding environment (Mualifin and Maswar, 2016).

\subsection{Disclosure of Sustainability Report}

Sustainability report is a practice of measuring, disclosing, and accountability efforts of an organization's performance in order to achieve sustainable development goals to stakeholders, both internal stakeholders and external stakeholders (GRI,
2006). From a business standpoint, sustainable development can be defined as an organization that meets the needs of its stakeholders or stakeholders today, either directly or indirectly without diminishing its ability to meet the needs of its stakeholders in the future (Dyllick and Hockerts, 2002).

The sustainability report not only presents financial information, but also provides non-financial information, which includes information on social activities and environments that enable an organization or company to grow sustainably (Elkington, 1997). The meaning of sustainability is a result of society that allows for future generations that will at least retain the same natural wealth as the current generation (Whitehead, 2006).

World Business Council for Sustainable Development (2000) outlines some of the benefits to be gained when an organization or company presents a sustainability report disclosure, including: a) Providing information to stakeholders, thereby enhancing the company's prospects and assisting in the transparency of financial statements; b) To help build the company's reputation, so as to contribute in improving brand value, market share, and long term customer loyality; c) Can make a picture of how the company in managing the risks it faces; d) Can be used as a simulation of leadership thinking and performance supported by the spirit of competition; e) Can develop and as a facility in implementing better management systems in managing environmental, economic and social impacts; f) May indirectly reflect the company's ability and readiness in meeting shareholder activities with long-term vision, as well as help demonstrate how to improve the value of the company in relation to social and environmental issues.

\subsection{Relationship between Going Concern Audit Opinion on Sustainability Report Disclosure}


According to SPAP (2011), going concern audit opinion is an audit opinion issued by the auditor to evaluate whether there is doubt about the ability of the entity to maintain its survival. This going concern audit opinion will be provided by an independent auditor if there is any doubt about the company in maintaining its business continuity. Mutchler (1985) states that there are several criteria for companies that will accept going-concern audit opinion, among others are: Companies that have problems with income; Companies that are under reorganization, Companies that have failed in interest payments; Companies that have received going concerns in the previous year; Companies that are in the process of liquidation; Companies with negative net income, negative cash flow, negative work income, negative working capital, and losses for 2 to 3 consecutive years; Companies that have negative retained earnings.

Based on the theory of legitimacy, every company needs a legitimacy for the sake of sustainability of its business (Rossi and Tarquinio, 2017). One concrete form of legitimacy is the disclosure of sustainability reports that have been presented by each company, both presented in an integrated report annually and separately. Chen et. al., (2012), states that the auditor uses the information contained in the company's sustainability report during the audit planning process in assessing a client's audit risk and is likely to decrease a going concern audit opinion on the company that has presented sustainability report company well. This indicates that the auditor will use a sustainability report containing additional company information as an auditor's judgment in giving his opinion. The auditor will assess that a company that has presented a sustainability report with complete, then the business going concern of the company will be guaranteed. Thus can be formulated the following hypothesis:
H. Going Concern Audit Opinion negatively affects the disclosure of sustainability report.

\subsection{Relationship between The Altman Z- Score Model Bankruptcy Theory to Sustainability Report Disclosure}

Altman (1968) was the first to apply Multiple Discriminant Analysis. This discriminant analysis is a statistical technique that identifies several kinds of financial ratios that are considered to have the most important value in influencing an event, then developing it in a model with the intent to facilitate inferring from an event. The model called Z-score in its original form is a linear model of a weighted financial ratio to maximize the model's ability to predict. This model basically aims to find the value of " $Z$ " is a value that indicates the condition of the company, whether in good health or not and show the performance of the company as well as reflect the prospects of the company in the future (Ramadhani and Lukviarman, 2009).

According to Altman (1968), in assessing a company will fail or not in the future can be divided into three groups: The condition of the bankrupt company (if the value of $\mathrm{Z}<1.1$ ); Condition of company in gray area (if value $1,1<Z<2,6$ ); and the condition of a healthy company or not bankrupt (if the value $Z>2.6$ ). Thus, if connected with the disclosure sustainability report it can be withdrawn logic that companies that have a value of $Z>2.6$ then indicates that the company in a healthy condition so that the business continuity of the company is guaranteed. One concrete form of guarantee of sustainability is the existence of the disclosure of sustainability report more complete. The statement can be formulated into the following hypotheses:

$H_{2}$. $Z$ value on the calculation of bankruptcy Altman Z-Score model positively affect the disclosure of sustainability report. 


\subsection{Relationship between Company Size on Sustainability Report Disclosure}

Company size is one of the factors that may affect some disclosure practices (Probohudono, A.N., Greg Tower, and Rusmin.R., 2013). Several studies have shown that firm size is one of the major determinants of disclosure of sustainability reports (Sumiani et.al., 2007; Dilling, 2010). The larger the company, the greater its appeal to the government, the general public, and other stakeholders (Puspita and Daljono, 2014). This has led to large companies likely to face closer scrutiny from their stakeholders, when compared to smaller companies. The presence of stricter supervision is due to the fact that large companies will have a greater impact on their stakeholders (Dissanayake et al., 2016).

Given the more stringent supervision of its stakeholders, large-scale companies will create greater social responsibility when compared to smaller companies. The existence of greater social responsibility, it will impact on the level of corporate legitimacy of its stakeholders who tend to be higher (Dissanayake et al, 2016). Thus, if associated with the theory of legitimacy, it can be indicated that the larger a company, the company will have a high level of legitimacy to its stakeholders.

Larger companies will tend to communicate a wider set of social responsibility items (Probohudono et.al., 2013). One of the company's ways to express its social responsibility is by presenting sustainability report. This statement is in line with research conducted by Sumiani et. al. (2007), who argued that company size is a factor affecting the sustainability report level, due to an increase in demand from stakeholders related to the social responsibility that has been done by the company. Based on this, it can be formulated hypothesis as follows:

$H_{3}$. Company size has a positive effect on sustainability report disclosure.

\subsection{Relationship between Company Age on Sustainability Report Disclosure}

In addition to firm size, the company's age is also assessed into one of the decisive factors in encouraging the presentation of sustainability reports (Kolk, 2003; Jenkins and Yakovleva, 2006). The age of the company usually refers to the length of time the company from the beginning stand up to now. The longer the company has been established, the company is expected to produce more sustainable reporting. This statement is in accordance with the results of research conducted by Delaney and Huselid (1996) that older companies will have a tendency to provide more sustainable information, when compared to newly established companies. By providing more sustainable information, it will automatically make the company have a higher level of legitimacy from its stakeholders.

Other studies have shown that there is a negative relationship between the sustainability report on the age of the firm, which means that more established companies will see less need to meet the demands of their growing stakeholders (Liu and Anbumozhi, 2009; Rettab, B., Brik, AB , and Mellahi, K., 2009). It shows that longstanding companies will face lower levels of legitimacy threat from their stakeholders. The existence of several different statements shows that the age of the company has become one of the factors that influence the company in presenting sustainability report. Thus, the hypothesis can be formulated as follows:

$H_{4}$. The age of the company has a positive effect on the disclosure of sustainability report.

\section{Research Methods}

\subsection{Research Design}

The object in this study is a nonfinancial SOEs company in Indonesia that has presented the financial statements and 
sustainability report, both presented separately or integrated with the annual report. The reason researchers choose nonfinancial SOE companies as the object of research because financial entities have special characteristics and treatment, which can't be equated with non-financial entities. The study sample consisted of 54 nonfinancial SOE companies in Indonesia with observation year during 2014-2016, so as to get the final sample which amounted to 162 observations. This research is quantitative and uses secondary data obtained from various sources, among others through the site http://www.bumn.go.id which is the official site of the Ministry of SOEs Republic of Indonesia, through the personal website of the relevant SOEs, as well as through the site http://www.idx.co.id for SOE companies that have been listed in Indonesia Stock Exchange.

\subsection{Research Variable}

\subsubsection{Independent Variable}

This study uses four kinds of independent variables. In measuring the business continuity (going concern) company, researchers will use the variable going audit opinion and value $\mathrm{Z}$ "from the calculation of bankruptcy Model Altman Z-Score. For going concern audit opinion variables will be measured using dummy variables, where firms receiving a going concern audit opinion will be coded 1, whereas firms that do not accept going-concern audit opinion will be coded 0 . Furthermore, for a $\mathrm{Z}$ value on $\mathrm{Z}$ Score can be calculated using the following equations (Altman, Hartzell, and Peck, 1995):

$$
Z "=6,56 \times 1+3,26 \times 2+6,72 \times 3+1,05 X 4
$$

where :

Z” : bankruptcy index

$X 1 \quad$ : working capital/total asset

$X 2 \quad:$ retained earnings / total asset

X3 :earnings before interest and taxes/total asset
X4 : book value of equity/book value of total liabilities

In addition, to assess the characteristics of the company researchers will use variable size of the company and the age of the company. Based on the research that has been done by Dissanayake et. al. (2016), that the firm size variable will be proxied by using the $\log$ of total assets, while for the age variable the company will be proxied with reference to the length of time since the entity / company is established until the time period of research.

\subsubsection{Dependent Variable}

The dependent variable in this study is the level of Sustainability Report (SR) disclosure present in the company's sustainability report, which is disclosed in the Sustainability Report Index (SRI). SRI will be assessed by comparing the amount of disclosures presented by the company to the amount of disclosures required by Global Reporting Initiative (GRI) 4.1. which consists of 91 disclosure indicators, where the disclosure indicators include: economic, environment, labor practices, human rights, society, and product responsibility. In addition to using GRI 4.1 guidelines. The researchers also used the disclosure guidelines set forth by the Financial Services Authority (OJK) Institution on POJK No.51 / POJK.03 / 2017 attachment consisting of 67 indicators. If the company presents the indicators set out in its Sustainability Report then it will be scored 1, but if the company does not present the predefined indicator it will be scored 0 .

\subsection{Data Analysis Technique}

Data analysis method used in this research is panel data regression analysis by using statistical tool in the form of software Eviews version 9.0. All data that has been collected will be presented using descriptive statistics consisting of: mean; median; deviation standard; maximum; and the 
International Journal of Economics, Business and Accounting Research (IJEBAR)

Peer Reviewed - International Journal

Vol-3, Issue-1, 2019 (IJEBAR)

ISSN: 2614-1280

http://www.jurnal.stie-aas/ijebar

minimum that will be presented in the table. Furthermore, in the hypothesis testing will be used general effects model, fixed effect, and random effects. From the three test models, the most appropriate one will be chosen. In choosing the best model will be done with chow test and hausman test. Regression model used in testing the hypothesis in this study is as follows:

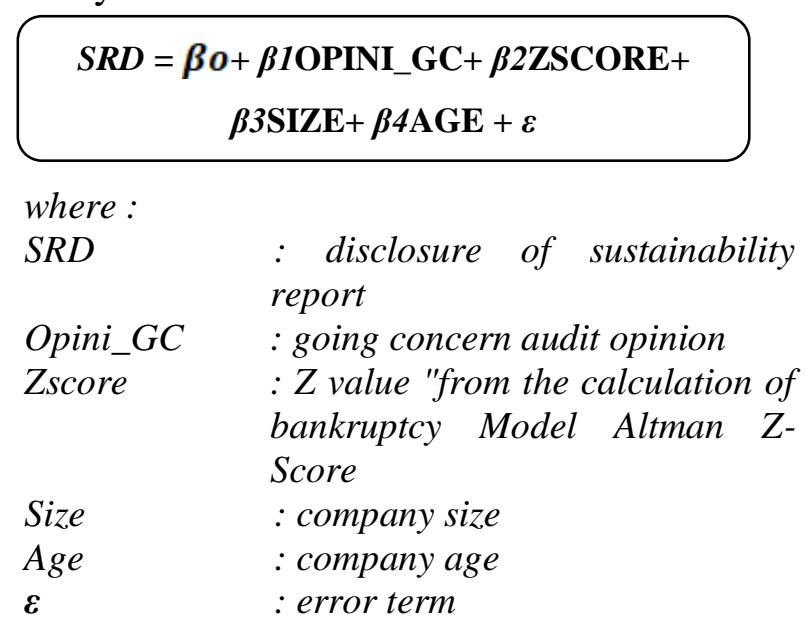

\section{Results and Discussion}

\subsection{Sustainability Report Disclosure Index}

Table 1 Sustainability Report Disclosure Index

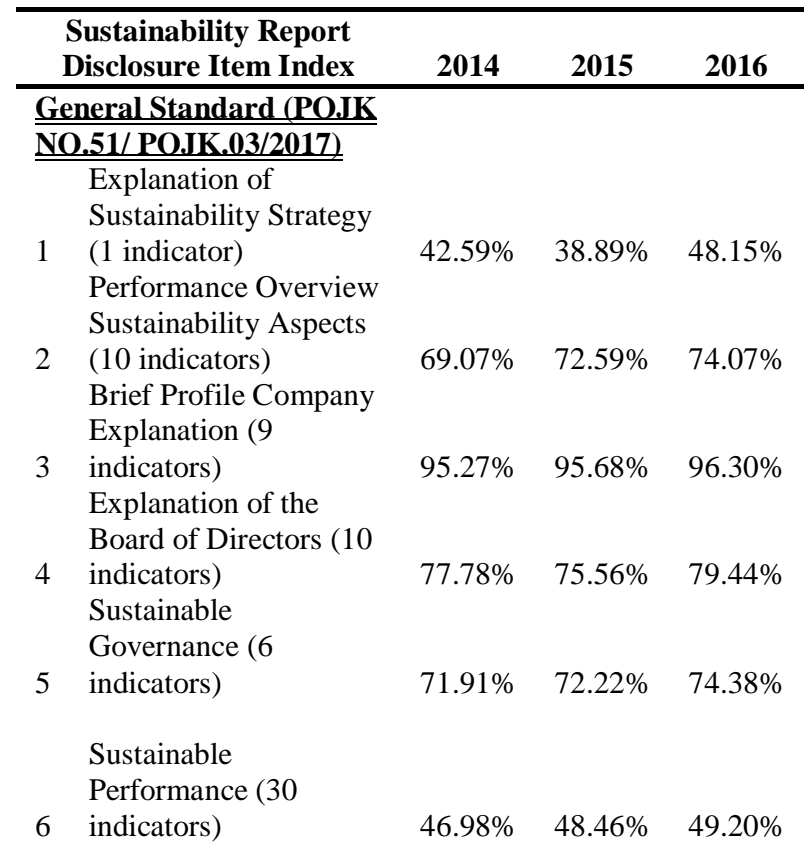

\begin{tabular}{|c|c|c|}
\hline $\begin{array}{l}\text { Written Verification of } \\
\text { Independent Party, If }\end{array}$ & $11.11 \%$ & $12.96 \%$ \\
\hline
\end{tabular}

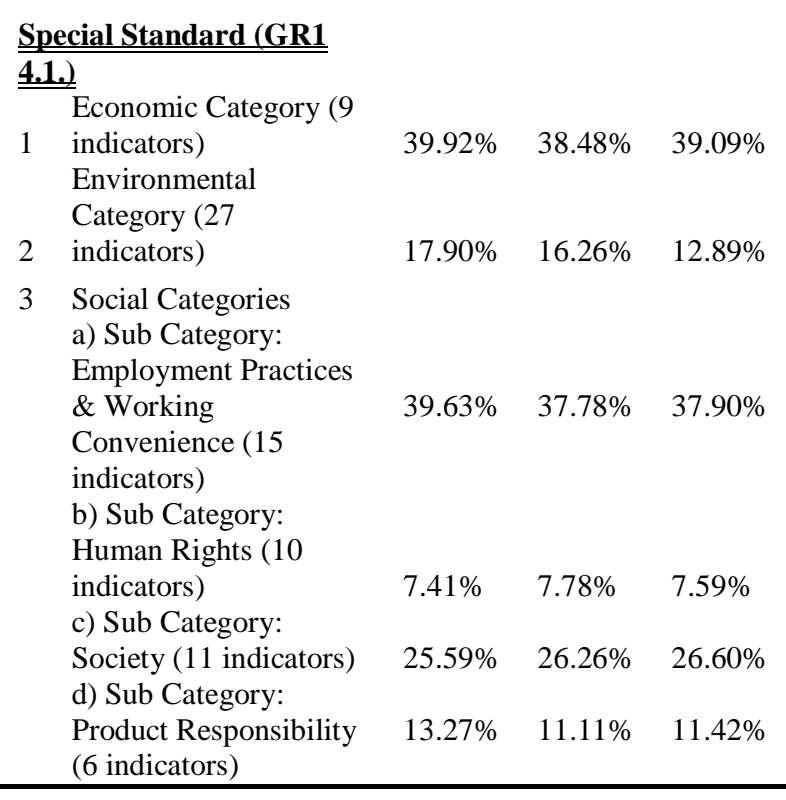

The table above illustrates that on every indicator in the disclosure sustainability report always change from year 2014-2016. Broadly speaking these indicators are increasing from year to year, but there are also some indicators that have decreased or constant. When viewed from the percentage above, the highest value lies in the "brief profile company explanation" indicator, which is part of the general standard of sustainability report disclosure. The value is $96.30 \%$, which indicates that almost all companies in the research sample have disclosed information about their company profile completely, for example include: vision, mission, name, address, phone number, business scale, brief description of product, etc. Furthermore, for the lowest value of $7.41 \%$ lies in the indicator "sub categories of human rights", which is part of a special standard. This indicator is always the lowest value every year and tends to be constant. This indicates that most companies have not provided information about disclosures related to human rights, for example: about incidents of discrimination security practices, customary rights, and all aspects related to human rights values. 
International Journal of Economics, Business and Accounting Research (IJEBAR)

Peer Reviewed - International Journal

Vol-3, Issue-1, 2019 (IJEBAR)

ISSN: 2614-1280

http://www.jurnal.stie-aas/ijebar

\subsection{Descriptive Statistics Analysis}

Table 2 Descriptive Statistics Test Results

\begin{tabular}{lcccccc}
\hline \multicolumn{1}{c}{ Variable } & $\mathbf{N}$ & Min & Max & Mean & Median & Std. Dev \\
\hline SRD & 162 & 10.00000 & 134.0000 & 60.83333 & 56.50000 & 20.97684 \\
OPINI_GC & 162 & 0.000000 & 1.000000 & 0.055556 & 0.000000 & 0.229772 \\
ZSCORE & 162 & -16.80000 & 19.69000 & 2.884074 & 2.595000 & 4.179827 \\
SIZE & 162 & 9.040000 & 15.11000 & 12.53660 & 12.70500 & 1.166758 \\
AGE & 162 & 7.500000 & 70.40000 & 40.20630 & 42.05000 & 15.07347 \\
\hline
\end{tabular}

Based on the descriptive statistical analysis table above (Table 2), it can be known the mean, median, maximum, minimum, and standard deviation of each variable. In the disclosure variable sustainability report shows the average value (mean) of 60.8 which means that the outline of SOE companies only reveal 60 indicators in sustainability report, with a maximum value of 134 indicators and a minimum value of 10 indicators. Furthermore, for the mean value of going concern audit opinion variable indicates that most SOE companies do not get the opinion in their audit report. For the Z-score variable, the mean value of 2.9 indicates that most state-owned enterprises are in good health. Furthermore, the firm size variables have an average weight of 12.5 which does not differ much from its

\subsection{Hypothesis Testing Results}

maximum value of 15.1 , thus indicating that the SOE firms that are the objects in this study have the same average size. In the firm's age variable, the average value, maximum value, and minimum value obtained show that the SOEs companies in this study have a very variable age. From the results of descriptive statistical tests, the researchers then tested the classical assumption to assess the quality of research data. The researchers tested the classical assumptions consisting of normality test, autocorrelation test, multicollinearity test, and heteroskedasticities test. Of the four test results indicate that the data in this study has passed and feasible to do regression analysis of panel data.

Table 3 Hypothesis Test Results

\begin{tabular}{lcccc}
\hline \hline \multicolumn{1}{c}{ Variable } & Coefficient & Std. Error & t-Statistic & Prob. \\
\hline \hline OPINI & -22.22131 & 7.615740 & -2.917813 & 0.0040 \\
ZSCORE & 0.598092 & 0.424902 & 1.407600 & 0.1612 \\
SIZE & 2.869471 & 1.329195 & 2.158804 & 0.0324 \\
AGE & 0.321921 & 0.103350 & 3.114865 & 0.0022 \\
C & 11.42624 & 17.44755 & 0.654891 & 0.5135 \\
\hline \hline R-squared & 0.172756 & & & \\
Adjusted R-squared & 0.151679 & & & \\
F-statistic & 8.196687 & & & \\
Prob(F-statistic) & 0.000005 & & & \\
\hline \hline
\end{tabular}


The table above shows the result of panel data regression analysis with least squares panel method with general effect estimation model (common) after chow test and hausman test. The result shows that the value of adjusted $\mathrm{R}^{2}$ is $15.2 \%$, which indicates that the variable of going concern opinion, Z-score, firm size, and age of company has explained $15.2 \%$ dependent variable i.e. sustainability report disclosure, and $84.8 \%$ explained other variables outside of this research model. In addition, the value of $F$ can also be seen from the value of Prob (F-statistic) significant at the level of $0.000005<0.05$ indicating that this research model is fit.

Based on the significance level of 0.05 , it can be concluded that the first hypothesis $\left(\mathrm{H}_{1}\right)$ is accepted, which means that going concern audit opinion has a negative effect on the disclosure of sustainability report. This result is in accordance with the theory expressed by Chen et al. (2012), that the auditor will use the information contained in the company's sustainability report in assessing a client's audit risk and is likely to decrease the audit opinion going concern on the company that has presented the sustainability report well. This indicates that the auditor will use the sustainability report as one of the auditor's judgments in giving his opinion. The auditor will judge that a company that has provided a sustainability report with complete, then the business going concern will be guaranteed, so that the auditors will not issue a going concern opinion in the audit report.

Unlike the previous hypothesis, the second hypothesis $\left(\mathrm{H}_{2}\right)$ has a significance value of 0.16 which means exceeds the 0.05 significance level, so the hypothesis is not accepted. These results indicate that the company's health condition calculated by Altman Z-Score Model has no positive effect on the level of sustainability report disclosure presented by the company. Companies that have a good health condition or free from loss does not necessarily present a complete sustainability report, and vice versa. This result is in line with the issue that occurred in recent times, where based on news released by detikFinance on August 29, 2017 and then, that there are some SOEs are still experiencing losses. Those losing SOEs have presented sustainability reports in their annual reports. Thus, it can be concluded that the level of disclosure sustainability report of a company can't reflect the health conditions of the company.

Further, for the third hypothesis $\left(\mathrm{H}_{3}\right)$, it shows a significance value of 0.03 which means that the hypothesis is accepted, since the value is below the 0.05 significance level. These results indicate that firm size has a positive influence on the level of sustainability report disclosure. This finding is in line with the study of Dissanayake et. al. (2016); Henri and Journeault (2008); and Jenkins and Yakovleva (2006) suggesting that there is a correlation between firm size and the high level of sustainability report presented. They argue that the larger the scale of the company, the resources that exist within the company is also certainly more and more adequate and professional, so that the demands of legitimacy from the increasing public can be overcome.

Based on table 3 above, the firm's age variable has a significance value of 0.00 , where the value is below the 0.05 significance level so that the fourth hypothesis $\left(\mathrm{H}_{4}\right)$ of this study is accepted. This result indicates that the age of a company has a positive influence on the disclosure of sustainability report. This statement is in line with the results of research conducted by Delaney and Huselid (1996) that older companies will have a tendency to provide more sustainable information, when compared to newly established companies. By providing more sustainable information, it will automatically 
make the company have a higher level of legitimacy from its stakeholders. Thus, the age of the firm is also seen as one of the decisive factors in encouraging the presentation of sustainability reports (Kolk, 2003; Jenkins and Yakovleva, 2006).

\section{Conclusion and Limitation}

This study provides empirical evidence of the relationship between the going concern of the company represented by the variable goinggoing audit opinion and the value of $\mathrm{Z}$ "from the calculation of bankruptcy Model Altman Z-Score, as well as company characteristics assessed using variable size and age of the company against the level of disclosure sustainability report on non-financial SOEs in Indonesia. Based on the results of tests that have been done, the researchers obtained the result that only the variable value $\mathrm{Z}$ "from the calculation of bankruptcy model Altman ZScore alone which has no significant effect, while for other variables have a significant influence on the level of disclosure sustainability report presented by the company. The variable of going concern audit opinion has a significant negative impact on the disclosure of sustainability report, while for variable size and age of company have positive significance influence on sustainability report disclosure. This result is consistent with some previous researchers who have conducted research in similar fields, such as Dissanayake et. al. (2016); Chen et al., (2012); Henri and Journeault (2008); Jenkins and Yakovleva (2006); Kolk, 2003; Delaney and Huselid (1996).

The results of this study has implications for related regulators, namely the Badan Usaha Milik Negara (BUMN) and / or the Otoritas Jasa Keuangan (OJK) to make a sustainability report. Thus, it is expected to be used companies to improve the completeness of the sustainability report in its annual report.

The limitation of this research lies in measuring the level of sustainability report disclosure that is in the company's sustainability report, researchers used the Sustainability Report Index (SRI) based on GRI 4.1 and the POJK No.51 / POJK.03 / 2017 attachment. These guidelines are not categorized according to the types of companies, where according to researchers each type of company has different parameters in terms of disclosure of items contained in the sustainability report. So, for the next study it can be used or added in other guidelines in the sustainability report, where the guidelines is expected to be in accordance with each type of company. Thus, the disclosure parameters of each type of company can be different, and the results are more accurate.

\section{References}

Altman, E.I .1968. Financial Ratios, Discriminan Analysis and The Prediction of Corporate Bankruptcy. The Journal of Finance. 23: 589-609.

,Harzell J, and Peck M. 1995. Emerging Market Corporate Bonds - A Scoring System.Salomon Brothers Emerging Market Bond Research.

Chen, L., Srinidhi, B.,Tsang, A., \& Yu, W. 2012. "Corporate Social Responsibility, Audit Fees, And Audit Opinions". SSRN: http://vvvvvv.ssrn.com.

Delaney, J.T., Huselid, M.A., 1996. The Impact of Human Resource Management Practices on Perceptions of Organizational Performance. Acad. Manag. J. 39 (4), 949969.

DetikFinance. 2017.'Ini daftar 24 BUMN yang Merugi". https://finance.detik.com/beritaekonomi-bisnis/3620207/ini-daftar-24bumn-yang-merugi. Diakses Tanggal 14 Oktober 2017.

Dilling, P.F. 2010. Sustainability reporting in a global context: what are the characteristics of corporations that provide high quality 
sustainability reports an empirical analysis. Int. Bus. Econ. Res. J. IBER 9 (1), 19-30.

Dissanayake, D., Carol, T., dan Maria X.L. 2016. Sustainability Reporting by Publicly Listed Companies in Sri Lanka : Journal of Cleaner Production, 0959-6526.

Dyllick, T., Hockerts, K., 2002. Beyond The Business Case for Corporate Sustainability. Bus. Strategy Environ. 11 (2), 130-141.

Elkington, J. 1997. Cannibals with Forks: The Triple Bottom Line of 21st Century Business. Capstone. Oxford.

Global Reporting Initiatives (GRI). 2006. Sustainability reporting Guidelines. www.globalreporting.org/ guidelines/ 062006 guidelines.asp. Diakses Tanggal 27 Oktober 2017.

Global Reporting Initiatives GRI. (2012). "Sustainability Reporting Guidelines, Global Reporting Initiative, London". http://www.globalreporting.org. Diakses Tanggal 12 Oktober 2017.

Henri, J.-F., Journeault, M., 2008. Environmental Performance Indicators: An Empirical Study of Canadian Manufacturing Firms. J. Environ. Manag. 87 (1), 165-176.

Ikatan Akuntan Indonesia. 2001. Standard Profesional Akuntan Publik, Seksi.341, Jakarta: Salemba Empat.

Ikatan Akuntan Indonesia. 2011. Standard Profesional Akuntan Publik, Jakarta : Salemba Empat.

Jenkins, H., Yakovleva, N., 2006. Corporate Social Responsibility in The Mining Industry: Exploring Trends in Social and Environmental Disclosure. J. Clean. Prod.14 (3), 271-284.

Kolk, A., 2003. Trends in Sustainability Reporting by The Fortune Global 250. Bus. Strategy Environ. 12 (5), 279-291.
Liu, X. dan V. Anbumozhi. 2009. Determinant Factors of Corporate Environmental Information Disclosure: An Empirical Study of Chinese Listed Companies. J. Clean. Prod. 17 (6), 593-600.

Md. Habib-Uz-Zaman, K., Islam, M.A., dan Johra, F.K., Khadem, A., 2011. Corporate sustainability reporting of major commercial banks in line with GRI: Bangladesh evidence. Soc. Responsib. J. 7 (3), 347-362.

Meryana, Ester. 2013. "Perusahaan Pembuat Laporan Keberlanjutan Kian Banyak di Indonesia". http: //swa.co.id/ businessresearch/ perusahaan-pembuat-laporankeberlanjutan-kian-banyak-di-indonesia. Diakses tanggal 23 Oktober 2017.

Mualifin, O.R. dan Maswar P.P., 2016. Dampak Pengungkapan Sustainability Report Terhadap Kinerja Keuangan dan Kinerja Pasar. Jurnal Ilmu dan Riset Akuntansi : Vol. 5, No. 5.

Mutchler, J.F. 1985. "A Multivariate Analysis of The Auditor's Going Concern Opinion Decision". Journal of Accounting Research.: Vol 23, No 2. Autumn. Pp 668682.

Nurrahman, Adimulya dan Sudarno. 2013. Pengaruh Kepemilikan Manajerial, Kepemilikan Institusional, dan Kepemilikan Asing Terhadap Praktik Pengungkapan Sustainability Report. Diponegoro Journal of Accounting: Vol.2, No.1, Hal. 1-14.

Pemerintah Indonesia. 2007. Undang-Undang No.40 Tahun 2007 Yang Mengatur Tentang Perseroan Terbatas. Lembaran Negara RI Tahun 2007, No.4756. Sekretariat Negara. Jakarta.

2009. Undang-Undang No.32 Tahun 2009 Yang Mengatur Tentang Perlindungan dan Pengelolaan Lingkungan Hidup. Lembaran Negara RI Tahun 2009, No.5059. Sekretariat Negara. Jakarta. 
International Journal of Economics, Business and Accounting Research (IJEBAR)

Peer Reviewed - International Journal

Vol-3, Issue-1, 2019 (IJEBAR)

ISSN: 2614-1280

http://www.jurnal.stie-aas/ijebar

Peraturan Otoritas Jasa Keuangan No.51/POJK.03/2017 Tentang Penerapan Keuangan Berkelanjutan Bagi Lembaga Jasa Keuangan, Emiten, dan Perusahaan Publik, LNRI 2017 Nomor 169.

Probohudono, Agung Nur, Greg Tower, dan Rusmin Rusmin. 2013. Risk Disclosure During The Global Financial Crisis. Social Responsibility Journal : Vo.9, No.1, pp.124-136.

Puspita, Anitya Ardiyani dan Daljono. 2014. "Analisis Faktor-Faktor yang Mempengaruhi Corporate Sustainability Performance". Diponegoro Journal of Accounting : Vol.3, No.,2, ISSN.22373806.

Ramadhani, A. R dan Lukviarman. 2009. Perbandingan Analisis Prediksi Kebangkrutan Menggunakan Model Altman Pertama, Altman Revisi, dan Altman Modifikasi dengan Ukuran dan Umur Perusahaan sebagai Variabel Penjelas (Studi pada Perusahaan yang Terdaftar di Bursa Efek Indonesia).Jurnal Siasat Bisnis, Universitas Indonesia.Jakarta.

Rettab, B., Brik, A.B., Mellahi, K., 2009. A Study of Management Perceptions of The Impact of Corporate Social Responsibility on Organisational Performance in Nemerging Economies: The Case of Dubai. J. Bus. Ethics 89 (3), 371-390.

Rossi, Adriana dan Tarquinio, Lara. 2017. "An Analysis of Sustainability Report Assurance Statements: Evidence From
Italian Listed Companies". Managerial Auditing Journal : Vol. 32 Issue: 6, pp.578602.

Sahay, A., 2004. Environmental reporting by Indian corporations. Corp. Soc. Responsib. Environ. Manag. 11 (1), 12-22.

Sari, M.P.Y. dan Marsono. 2013. Pengaruh Kinerja Keuangan, Ukuran Perusahaan dan Corporate Governance Terhadap Pengungkapan Sustainability Report. Skripsi. Universitas Diponegoro. Semarang.

Suchman, M.C. 1995. "Managing Legitimacy: Strategic and Institutional Approaches". Academy of Management Review, Vol. 20 No. 3, pp. 571-610.

Sumiani, Y., Haslinda, Y., Lehman, G., 2007. Environmental Reporting in A Developing Country: A Case Study on Status and Implementation in Malaysia. J. Clean. Prod. 15 (10), 895-901.

Wibowo, I. 2014. Dampak Pengungkapan Sustainability Report Terhadap Kinerja Keuangan dan Kinerja Pasar Perusahaan. Simposium Nasional Akuntansi XVII Mataram, Lombok 24-27 September 2014.

World Business Council for Sustainable Development (WBCSD). 2000. "WBCSD's first report-Corporate social Responsibility". https://www.wbcsd.org. Diakses Tanggal 16 Oktober 2017.

Whitehead, John. 2006. "Global Warming and Sustainability".http//www.envecon.net. Diakses tanggal 27 oktober 2017. 